\title{
Article/Artigo
}

\section{Sand fly captures with Disney traps in area of occurrence of Leishmania (Leishmania) amazonensis in the State of Mato Grosso do Sul, mid-western Brazil}

\author{
Capturas de flebotomíneos com armadilhas de Disney em área de ocorrência de Leishmania \\ (Leishmania) amazonensis no Estado de Mato Grosso do Sul, Região Centro-Oeste do Brasil
}

\begin{abstract}
Maria Elizabeth Cavalheiros Dorval ${ }^{1}$, Tulia Peixoto Alves ${ }^{1}$, Geucira Cristaldo ${ }^{1}$, Hilda Carlos da Rocha ${ }^{1}$, Murilo Andrade Alves ${ }^{1}$, Elisa Teruya Oshiro ${ }^{1}$, Alessandra Gutierrez de Oliveira ${ }^{1}$, Reginaldo Peçanha Brazil ${ }^{2}$, Eunice Aparecida Bianchi Galati ${ }^{3}$ and Rivaldo Venancio da Cunha ${ }^{1}$
\end{abstract}

\begin{abstract}
Introduction: The work was conducted to study phlebotomine fauna (Diptera: Psychodidae) and aspects of American cutaneous leishmaniasis transmission in a forested area where Leishmania (Leishmania) amazonensis occurs, situated in the municipality of Bela Vista, State of Mato Grosso do Sul, Brazil. Methods: The captures were conducted with modified Disney traps, using hamster (Mesocricetus auratus) as bait, from May 2004 to January 2006. Results: Ten species of phlebotomine sandflies were captured: Brumptomyia avellari, Brumptomyia brumpti, Bichromomyia flaviscutellata, Evandromyia bourrouli, Evandromyia lenti, Lutzomyia longipalpis, Psathyromyia campograndensis, Psathyromyia punctigeniculata, Psathyromyia shannoni and Sciopemyia sordellii. The two predominant species were Ev bourrouli (57.3\%) and Bi flaviscutellata (41.4\%), present at all sampling sites. Two of the 36 hamsters used as bait presented natural infection with Leishmania. The parasite was identified as Leishmania (Leishmania) amazonensis. Conclusions: Analysis of the results revealed the efficiency of Disney traps for capturing Bichromomyia flaviscutellata and the simultaneous presence of both vector and the Leishmania species transmitted by the same can be considered a predictive factor of the occurrence of leishmaniasis outbreaks for the human population that occupies the location.
\end{abstract}

Key-words: Phlebotominae. Bichromomyia flaviscutellata. Animal bait. Natural infection.

\begin{abstract}
RESUMO
Introdução: $\mathrm{O}$ estudo foi realizado com o objetivo de estudar a fauna de flebotomíneos (Diptera: Psychodidae) e aspectos ligados à transmissão da leishmaniose tegumentar americana em uma área florestal com ocorrência de Leishmania (Leishmania) amazonensis, situada no município de Bela Vista, Estado do Mato Grosso do Sul, Brasil. Métodos: As capturas de flebotomíneos foram realizadas utilizando-se armadilhas tipo Disney modificadas, com isca roedor, Mesocricetus auratus, no período de maio de 2004 a janeiro de 2006. Resultados: As coletas resultaram na identificação de 10 espécies de Phlebotominae: Brumptomyia avellari, Brumptomyia brumpti, Bichromomyia flaviscutellata, Evandromyia bourrouli, Evandromyia lenti, Lutzomyia longipalpis, Psathyromyia campograndensis, Psathyromyia punctigeniculata, Psathyromyia shannoni e Sciopemyia sordellii. As duas espécies predominantes foram Ev bourrouli, com 57,3\% dos espécimes coletados, e Bi. flaviscutellata, representada por $41,4 \%$ e que esteve presente em todos os locais amostrados. Dois hamsters sentinelas adquiriram a infecção natural, sendo os isolados identificados como Leishmania amazonensis. Conclusões: Os resultados mostram a eficiência das armadilhas Disney para captura de Bichromomyia flaviscutellata, e a presença simultânea de ambos, o vetor e a espécie de Leishmania por ele transmitida pode ser considerada um fator preditor da ocorrência de leishmaniose para a população humana que permanecer nesse local.
\end{abstract}

Palavras-chaves: Phlebotominae. Bichromomyia flaviscutellata. Isca animal. Infecção natural.

1. Federal University of Mato Grosso do Sul, Campo Grande, MS, Brazil. 2. Oswaldo Cruz Institute, Oswaldo Cruz Foundation, Rio de Janeiro, RJ, Brazil. 3. Department of Epidemiology, Public Health Faculty, University of São Paulo, São Paulo, SP, Brazil.

Address to: Dra. Maria Elizabeth Cavalheiros Dorval. Laboratório de Parasitologia/DPA/CCBS/UFMS Caixa Postal 549, 79070-900 Campo Grande, MS, Brasil.

Phone: 5567 3345-7369; Fax: $55673345-7314$

e-mail: bethparasito@nin.ufms.br

Received in 22/04/2010

Accepted in 21/07/2010

\section{INTRODUCTION}

Leishmaniasis have been regarded as an important public health problem in Mato Grosso do Sul over the last ten years. A rich variety of sandfly species in different ecotopes has been identified in several ecological studies conducted in this state. These studies have indicated new species or have reinforced the role that some of them play in the transmission of leishmaniasis to the population of different municipalities, contributing to current understanding of the epidemiology of these diseases in the state ${ }^{1-6}$.

The identification of phlebotomine sandflies, their habits, theirindices of infection with different Leishmania species and knowledge concerning the relationship between them and their vertebrate and invertebrate hosts are essential for understanding leishmaniasis epidemiology, assisting prevention and surveillance measures in the areas where the disease occurs ${ }^{7,8}$.

Reports of Bichromomyia flaviscutellata in Mato Grosso do Sul are relatively recent ${ }^{2,6}$, as is the confirmation of human and animal cases of American cutaneous leishmaniasis (ACL) associated with Leishmania (Leishmania) amazonensis infection ${ }^{9,10}$. With the purpose of improving current understand regarding leishmaniasis epidemiology in the municipality of Bela Vista, MS, an area in which human cases occur, investigation of the phlebotomine fauna attracted to Disney traps was conducted using hamsters as baits, a recognized attraction for L. amazonensis vectors.

\section{METHODS}

The municipality of Bela Vista (SL: $22^{\circ} 06^{\prime} 32^{\prime \prime}$ and WL: $\left.56^{\circ} 31^{\prime} 16^{\prime \prime}\right)$ is located in the southwestern region of the State of Mato Grosso do Sul, in the geographical microregion of Bodoquena. It has an area of $5,315 \mathrm{~km}^{2}$ $\left(2,050 \mathrm{mi}^{2}\right)$ and its borders are: the municipality of Jardim to the north; The Republic of Paraguay to the south, the municipality of Antônio João to the east and 
the municipality of Caracol to the west. Bela Vista is located on the border of the River Apa, opposite the Bella Vista district, Paraguay; its altitude is $180 \mathrm{~m}$ above sea level and the distance from the state capital, Campo Grande, is $349 \mathrm{~km}(217 \mathrm{mi})^{11}$.

According to the Brazilian Institute of Geography and Statistics (Instituto Brasileiro de Geografia e Estatística, IBGE) ${ }^{12}$, of the original vegetation cover recorded for the region, only a few seasonal semideciduous forest-like formations are left. The vegetation predominantly consists of savannah-like formations, seasonal forest and savannah.

The work was conducted in a reserve area belonging to the $10^{\text {th }}$ Mechanized Cavalry Regiment ( $10^{\circ}$ Regimento de Cavalaria Mecanizado, $10^{\circ} \mathrm{RCMec}$ ), located in the urban area and systematically used for military training.

\section{Capture of sandflies}

Six modified Disney traps ${ }^{13}$, associated with rodent bait, hamster (Mesocricetus auratus), were used. The hamsters were maintained in plastic cages in accordance with population density recommendations ${ }^{14}$, with a bed of wood shavings consisting of Pinnus sp, and were offered water and commercial ration Nuvilab CR-1 ${ }^{\circledR}$ (Nuvital, Curitiba, PR, Brazil) ad libitum. The cages were cleaned and the feed complemented on a weekly basis.

Thirty-six hamsters of both sexes, originating from the animal house of the Laboratory of Parasitology/Department of Pathology of the Federal University of Mato Grosso do Sul (Universidade Federal de Mato Grosso do Sul, UFMS) were used.

The traps were installed in the woods, about $20 \mathrm{~cm}$ from the ground, with changes of the sentinel animal every three months or when the general condition of the hamster was impaired (wasting, fur alteration, skin lesions). Once a week, a military officer trained by the research team examined the hamsters for possible lesions. When the hamster was taken out of the trap, it was maintained in the animal house of the Laboratory of Parasitology of UFMS for eight months so that Leishmania infection could be investigated.

The catches began in May 2004 and ended in April 2006.

The insects attracted to the hamster adhered to plates previously smeared with castor oil and, on a weekly basis, were collected with the aid of a soft, thin-ended brush, stored in flasks with isopropanol and maintained in the refrigerator until identification. The females were identified through exposure and morphological recognition of the genitalia; and the males, after clarification in the Laboratory of Parasitology. Specific identification and terminology were performed according to Galati ${ }^{15}$.

Williams Geometric Mean ${ }^{16}$ was used to quantify the frequency of some data.

Due to the nonexistence of meteorological data for the town, climate records from the Meteorological Station of the Airport of Ponta Porã, MS (Southwestern Regional Superintendency/ Navigation Management), located approximately 100km (62mi) from Bela Vista, were used.

\section{Ethical}

This study was approved by the Ethics Committee on the Use of Animals (Comissão de Ética no Uso de Animais, CEUA) of the UFMS, protocol no. 109/2006.

\section{RESULTS}

A total of 1,191 sandflies ( 622 males and 529 females) belonging to 10 species were collected: Bichromomyia flaviscutellata, Brumptomyia avellari, Brumptomyia brumpti, Evandromyia bourrouli, Evandromyia lenti,Lutzomyia longipalpis, Psathyromyia campograndensis, Psathyromyia punctigeniculata, Psathyromyia shannoni and Sciopemyia sordellii.

Table 1 presents the total number of species captured at the different sites. The male/female ratio for all specimens collected was 1.2:1.0, influenced by the large number of Ev bourrouli males. For Bichromomyia flaviscutellata, the ratio was 1:16.6, indicating a higher attraction of females to the traps.

The two predominant species were Ev bourrouli, accounting for $57.3 \%$ of the specimens, and Bichromomyia flaviscutellata, accounting for $41.4 \%$ and present at all the sites. The other species were sporadically present in the traps, in total, accounting for $1.3 \%$ of the overall specimens.

Among the capture sites, the Survival Station (Pista de Sobrevivencia) and the First Aid Station (Pista de Primeiros Socorros) presented the highest density of specimens, $70.1 \%$ and $16.5 \%$, respectively.

Evandromyia bourrouli, captured only in the Survival Station, had a high density and presented a peak in November and December 2005 , with $99.9 \%$ (681) of the specimens collected during the entire sample period.

TABLE 1 - Number of phlebotomines captured in Disney traps installed in forested areas of the $10^{\text {th }}$ Mechanized Cavalry Regiment $\left(10^{\circ}\right.$ RCMec $)$ in the municipality of Bela Vista, MS, from May 2004 to April 2006.

\begin{tabular}{|c|c|c|c|c|c|c|c|c|c|c|c|c|c|c|c|c|c|}
\hline \multirow[b]{2}{*}{ Specimens } & \multirow{2}{*}{$\begin{array}{l}\text { Site } \\
\text { Sex }\end{array}$} & \multicolumn{2}{|c|}{$\begin{array}{l}\text { Rope } \\
\text { station }\end{array}$} & \multicolumn{2}{|c|}{$\begin{array}{l}\text { First aid } \\
\text { station }\end{array}$} & \multicolumn{2}{|c|}{$\begin{array}{c}\text { Camping } \\
\text { area }\end{array}$} & \multicolumn{2}{|c|}{$\begin{array}{l}\text { Squadron } \\
\text { base }\end{array}$} & \multicolumn{2}{|c|}{$\begin{array}{c}\text { Survival } \\
\text { station (edge) }\end{array}$} & \multicolumn{2}{|c|}{$\begin{array}{c}\text { Survival } \\
\text { station (back) }\end{array}$} & \multicolumn{2}{|c|}{ Total } & \multicolumn{2}{|c|}{ Total } \\
\hline & & $\mathrm{M}$ & F & M & F & M & $\mathrm{F}$ & $\mathrm{M}$ & $\mathrm{F}$ & M & $\mathrm{F}$ & M & $\mathrm{F}$ & M & $\mathrm{F}$ & $\mathrm{n}$ & $\%$ \\
\hline \multicolumn{2}{|c|}{ Bichromomyia flaviscutellata } & 4 & 14 & 8 & 186 & 6 & 70 & 5 & 25 & - & 22 & 5 & 148 & 28 & 465 & 493 & 41.4 \\
\hline \multicolumn{2}{|c|}{ Brumptomyia avellari } & - & - & - & - & 1 & - & 3 & - & - & - & - & - & 4 & 0 & 4 & 0.3 \\
\hline \multicolumn{2}{|c|}{ Brumptomyia brumpti } & - & - & - & 1 & 2 & - & - & - & 1 & - & - & - & 3 & 1 & 4 & 0.3 \\
\hline \multicolumn{2}{|c|}{ Evandromyia bourrouli } & - & - & - & - & - & - & - & - & 556 & 95 & 26 & 5 & 582 & 100 & 682 & 57.3 \\
\hline \multicolumn{2}{|c|}{ Evandromyia lenti } & - & - & - & - & - & - & 1 & 1 & - & - & - & - & 1 & 1 & 2 & 0.2 \\
\hline \multicolumn{2}{|c|}{ Lutzomyia longipalpis } & - & - & - & - & 1 & - & 1 & - & - & - & - & - & 2 & - & 2 & 0.2 \\
\hline \multicolumn{2}{|c|}{ Psathyromyia campograndensis } & - & - & - & - & - & - & - & - & - & - & - & 1 & - & 1 & 1 & 0.1 \\
\hline \multicolumn{2}{|c|}{ Psathyromyia punctigeniculata } & - & - & - & - & - & 1 & & - & - & - & - & - & - & 1 & 1 & 0.1 \\
\hline \multicolumn{2}{|c|}{ Psathyromyia shannoni } & - & - & - & - & - & - & - & - & 1 & - & - & - & 1 & - & 1 & 0.1 \\
\hline \multicolumn{2}{|c|}{ Sciopemyia sordellii } & - & - & 1 & - & - & - & - & - & - & - & - & - & 1 & - & 1 & 0.1 \\
\hline \multicolumn{2}{|l|}{ Total } & 4 & 14 & 9 & 187 & 10 & 71 & 32 & 29 & 558 & 117 & 9 & 151 & 622 & 569 & 1,191 & 100.0 \\
\hline
\end{tabular}


In the first year of study, observations were severely impaired due to the constant changes in the trap sites due to theft episodes. Thus, for plotting graphs and analysis of seasonal distribution, only specimens of Bichromomyia flaviscutellata captured between May 2005 and April 2006 were used.

The monthly rainfall, the monthly average temperature and the Bichromomyia flaviscutellata frequencies are plotted in Figure 1. The species was captured practically throughout the entire year, with an abrupt fall in October associated with drier periods.
The seasonal distribution of Bi flaviscutellata females obtained by Williams' Geometric Mean is shown in Figure 2. The highest values occurred in winter, when the captures were at least 3.5 times higher than those in other seasons.

Among the 36 sentinels exposed during the whole period in the area, two of them presented ACL-like lesions. The parasite was characterized as Leishmania (Leishmania) amazonensis. The hamsters had been placed in traps installed in the Survival Station in March 2006 and were removed in early May, when field work was completed.

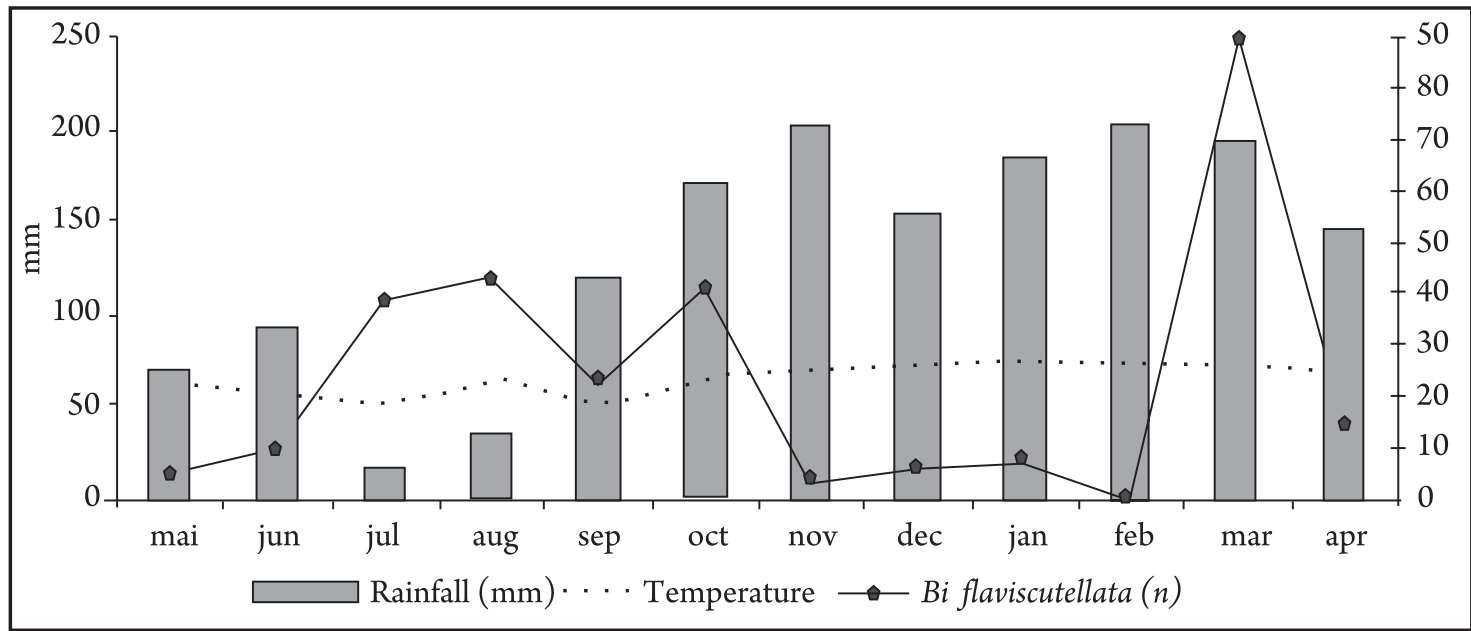

FIGURE 1 - Rainfall and average monthly temperature from May 2005 to April 2006, and monthly distribution of Bi flaviscutellata specimens caught in Disney traps in forested areas of the $10^{\text {th }}$ Mechanized Cavalry Regiment $\left(10^{\circ} \mathrm{RCMec}\right)$ in the municipality of Bela Vista, MS.

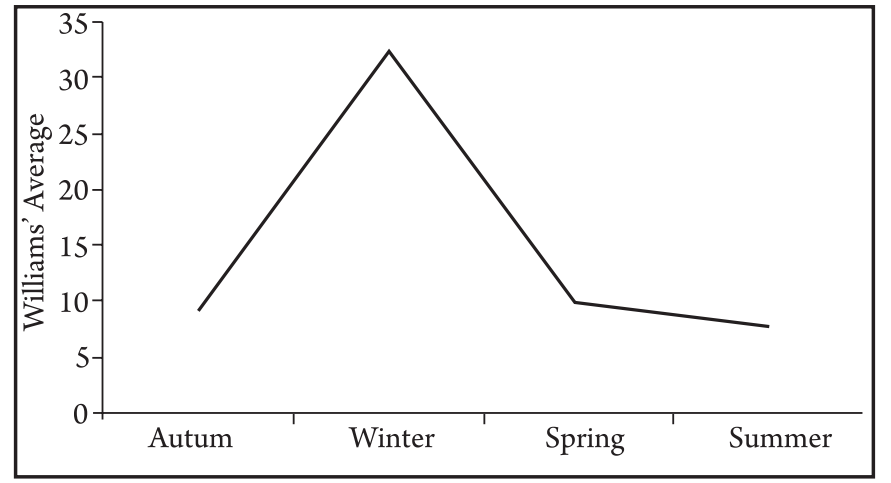

FIGURE 2 - Seasonal distribution of Bi. flaviscutellata females caught in Disney traps installed in forested areas of the $10^{\text {th }}$ Mechanized Cavalry Regiment $\left(10^{\circ} \mathrm{RCMec}\right)$ in the municipality of Bela Vista, MS, from May 2005 to April 2006.

\section{DISCUSSION}

Depending on aspects inherent to the behavior of phlebotomine, such as light attraction, feeding habits and tropisms, the capture methods offer diverse estimates on the relative abundance of different species ${ }^{17}$.

The results obtained with Disney traps complement information concerning the phlebotomine fauna in the area under study. Automatic light traps and Shannon traps were used and 354 and 454 specimens, belonging to 18 species of phlebotomine, were captured, respectively ${ }^{18}$.

The efficiency of Disney traps for Bichromomyia flaviscutellata was evident, as this was the second most abundant species when both sexes were considered, and the first in relation to females. With the other two methods, automatic light traps and Shannon traps, the species was present in low density, $1.1 \%$ and $5.9 \%$, respectively. This indicates the lowlevel of light and man attraction to Bichromomyia flaviscutellata. This species is recognized as the main vector of $L$. amazonensis ${ }^{19-21}$. Although it is reported as predominant in anthropophilic phlebotomine fauna in areas of non-climatic vegetation cover in the Amazon ${ }^{22}$, it is still regarded as a species with nocturnal habits, barely attracted to $\operatorname{man}^{23-27}$. This is a strictly wild species, found mostly in humid forests, especially those temporarily flooded ${ }^{27}$. However, it has been shown to be resistant to ecological changes and adaptable to different types of vegetation $^{22,28,29}$. It is found in anthropic environment ${ }^{6,28,30-32}$, which could contribute to increasing its distribution area in the country.

In the kind of trap used, in which neither human nor light interference occurs, the capture of a large number of female specimens reflects the greater power of attraction of the animal bait, corroborating the statement that this species has feeding preference for rodents ${ }^{19,22,26}$.

Although species of wild rodents, proven reservoirs of L. amazonensis, have not been used as baits and further studies regarding these animals are needed, the simultaneous presence of both the vector and the Leishmania species transmitted by the same ${ }^{9}$ may be considered a predictive factor of the occurrence of leishmaniasis outbreaks when the military staff remain in the site at night.

Although a larger number of specimens have been captured in the First Aid Station and in the Survival Station, Bi flaviscutellata was present in all the traps, which indicates that it is either distributed throughout the training area or actively spreads in search of food. The large amount of organic material deposited in the forest soil, such as leaves and the remains of decomposing plants, equine feces and leftovers, as well as the dense vegetation with predominance of arborous extract with leaf-falling species surrounding a glade, may 
favor the occurrence of breeding sites. On the other hand, anthropic wastes may favor the rodent populations, which, as previously noted, are attractive to Bichromomyia flaviscutellata.

While studying the seasonal variation of Bichromomyiaflaviscutellata in forested areas, Shaw and Lainson ${ }^{27}$ observed that during the driest season, from June through November, the population of these insects increased, reaching its peak around December. In the area studied, the fact that the Williams' Geometric Mean was 3.5 times higher in the winter in relation to other seasons also indicates that the highest frequency of the species is associated with the driest period. The peak observed at the end of the summer may be explained by the fact that a larger quantity of Bi.flaviscutellata individuals remained in larval stage for a longer period, when the soil was still excessively humid.

The use of such an area for military training occurs between March and May, when there is a greater offer of food to rodents, attracted to anthropic wastes, which may lead to greater circulation of L. amazonensis. In addition, a peak of Bichromomyia flaviscutellata was observed, which might explain the natural infection caused by L. amazonensis in the sentinel in March.

Thus, when verifying higher regularity of Bichromomyia flaviscutellata specimens during the driest period (July-September), it can be concluded that the risk of ACL transmission also increases if the human population is exposed in the area.

However, in periods in which averages are not so high, as occurred at the end of the summer, the risk of parasitic transmission may also occur, since, depending on climate and endogenous factors of Bichromomyia flaviscutellata species, it could present an abrupt increase in density, i.e., show explosive behavior. Moreover, if the vector explosion and the exposure of military personnel for training coincide, as reported during the analyzed period, outbreaks may occur. A case in point is the probable period of infection already reported for human cases ${ }^{9}$. The confirmation of natural infection of the sentinel exposed during the peak of this species (March) reinforces this point.

In compliance with these observations, it is suggested that military training in the forested area should occur from November through February, when Bichromomyia flaviscutellata density is diminished.

Evandromyia bourrouli, a species whose habitat includes forests and armadillo burrows ${ }^{33}$, was captured in high density by this method, and the fact that practically all females were engorged seems to determine their rodentophilic habit. In captures conducted with light traps, the result is always lower and the specimens are collected in both forested areas and anthropic environment, especially in the mid-western and north-eastern regions $s^{6,28,34}$.

The larger number of Ev bourrouli males may be attributed to factors already reported for other species of sandflies and traps, such as the installation of traps close to insect breeding and sheltering sites; the attraction of the males for copula during feeding and the males releasing pheromones, thus attracting more specimens of the same $\operatorname{sex}^{10,35-38}$. When comparing males and females captured in Disney traps, the collection of a reduced number of Evandromyia bourrouli bourrouli females (14.7\%), compared to Bichromomyia flaviscutellata (94.3\%), not only indicates a higher preference of the latter for rodents, but also seems to show distinct behavior of the respective males. It is possible that Ev. bourrouli males are more attracted to kairomones liberated by vertebrates ${ }^{39}$ and that they liberate aggregation pheromones and then attract other males. These characteristics are absent or less enhanced in Bichromomyia flaviscutellata.
Analysis of the results showed that, similar to other areas of ACL occurrence in the State of Mato Grosso do Sul ${ }^{4,40,41}$, disease transmission is associated with wild vector patterns and with human exposure to vectors in their natural habitat.

Thus, despite recognizing the importance of military training, especially as far as the defense of the country's frontiers is concerned, it is necessary to plan such activities for periods of lower vector density and to design measures of individual protection, in an attempt to reduce the contact with the vector and the risk of acquiring the parasite.

\section{ACKNOWLEDGMENTS}

The authors would like to thank the Command and the military of the $10^{\circ} \mathrm{RCMec}$ for their unconditional support for the study and the research team; the Coordenadoria de Controle de Vetores da Secretaria de Estado de Saúde, especially Mr. Elias Monteiro, for logistic support, and Mr. João Anastácio, for his collaboration in the field work; Military servicemen André Flávio Maria Zimmermann and Claudemar Borges Dias, for the usual reception and tireless collaboration in the captures; and Dra. Elisa Cupolillo for the identification of the parasite.

\section{CONFLICT OF INTEREST}

The authors declare that there is no conflict of interest.

\section{FINANCIAL SUPPORT}

Fundação de Apoio ao Desenvolvimento do Ensino, Ciência e tecnologia do Estado de Mato Grosso do Sul-FUNDECT/DECIT (00645-03), UFMS.

\section{REFERENCES}

1. Galati EAB, Nunes VLB, Boggiani PC, Dorval MEC, Cristaldo G, Rocha HC, et al. Phlebotomines (Diptera, Psychodidae) in caves of the Serra da Bodoquena, Mato Grosso do Sul State, Brazil. Rev Bras Entomol 2003; 7:283-296.

2. Galati EAB, Nunes VLB, Boggiani PC, Dorval MEC, Cristaldo G, Rocha HC, et al. Phlebotomines (Diptera: Psychodidae) in forested areas of the Serra da Bodoquena, state of Mato Grosso do Sul, Brazil. Mem Inst Oswaldo Cruz 2006; 101:175-193.

3. Galati EAB, Nunes VLB, Cristaldo G, Rocha HC. Aspectos do comportamento da fauna flebotomínea (Diptera:Psychodidae) em foco de leishmaniose visceral e tegumentar na Serra da Bodoquena e área adjacente, Estado de Mato Grosso do Sul, Brasil. Rev Patol Trop 2003; 32:235-261.

4. Galati EAB, Nunes VLB, Dorval MEC, Oshiro ET, Cristaldo G, Espíndola MA, et al. Estudo dos flebotomíneos (Diptera, Psychodidae) em área de leishmaniose tegumentar no Estado de Mato Grosso do Sul, Brasil. Rev Saude Publica 1996; 30:115-128.

5. Galati EAB, Nunes VLB, Rego-Jr FA, Oshiro ET, Chang MR. Estudo de flebotomíneos (Diptera: Psychodidae) em foco de leishmaniose visceral no Estado de Mato Grosso do Sul, Brasil. Rev Saude Publica 1997; 31:378-390.

6. Oliveira AG, Andrade-Filho JD, Falcão AL, Brazil RP. Estudo de flebotomíneos (Diptera, Psychodidae, Phlebotominae) na zona urbana da cidade de Campo Grande, Mato Grosso do Sul, Brasil. 1999-2000. Cad Saude Publica 2003; 19:933-944.

7. Cupolillo E, Momen H, Grimaldi-Jr G. Genetic diversity in natural populations of New World Leishmania. Mem Inst Oswaldo Cruz. 1998; 93:663-668.

8. Michalsky EM, Fortes-Dias CL, Pimenta PFP, Secundino NFC, Dias ES. Avaliação da PCR na investigação de Leishmania spp em flebotomíneos experimentalmente infectados (Diptera: Psychodidae: Phlebotominae). Rev Inst Med Trop São Paulo 2002 ; 44:255-259. 
9. Dorval MEC, Oshiro ET, Cupollilo E, Camargo ANC, Alves TP. Ocorrência de leishmaniose tegumentar americana no Estado do Mato Grosso do Sul (Brasil) associada à infecção por Leishmania (Leishmania) amazonensis. Rev Soc Bras Med Trop 2006; 39:43-46.

10. Souza AI, Barros EMS, Ishikawa E, Ilha IMN, Marin GRB, Nunes VLB. Feline leishmaniasis due to Leishmania (Leishmania) amazonensis in Mato Grosso do Sul State, Brazil. Vet Parasitol 2005; 128:41-45.

11. Secretaria Municipal de Saúde. Bela Vista. Mato Grosso do Sul. Plano Municipal de Saúde de Bela Vista 1997 a 2001. Bela Vista; 2001.

12. Instituto Brasileiro de Geografia e Estatística (IBGE). Produção Extrativa Vegetal. Rio de Janeiro; 2002.

13. Dorval MEC, Alves TP, Oliveira AG, Brazil RP, Galati EAB, Cunha RV. Modification of Disney trap for capture of sand flies (Diptera: Psychodidae: Phlebotominae). Mem Inst Oswaldo Cruz 2007; 102:877-878.

14. Institute of Laboratory Animal Resources. National Research Council. Guide for care and use of laboratory animals. National Academic Press; 1996.

15. Galati EAB. Classificação de Phlebotominae. In: Rangel EF, Lainson R, editors. Flebotomíneos do Brasil. Rio de Janeiro: Fundação Oswaldo Cruz; 2003. p.23-51.

16. Haddow AJ. Studies on the biting-habits and medical importance of East African mosquitos in the genus Aedes. I. Subgenera Aedimorphus, Banksinella and Nunnius. Bull Entomol Res 1960; 50:759-779.

17. Killick-Kendrick R. Methods for the study of phlebotomine sand-flies. Appendix II. The Leishmaniases in Biology and Medicine. Peters \& Killick-Kendrick editors. London: Academic Press; 1987. p.473-497W.

18. Dorval MEC, Cristaldo G, Rocha HC, Alves TP, Alves MA, Oshiro ET, et al. Phlebotomine fauna (Diptera: Psychodidae) of an American cutaneous leishmaniasis endemic area in the state of Mato Grosso do Sul, Brazil. Mem Inst Oswaldo Cruz 2009; 104:695-702.

19. Lainson R, Shaw JJ. Leishmaniasis in Brazil: I. Observations on enzootic rodent leishmaniasis - incrimination of Lutzomyia flaviscutellata (Mangabeira) as the vector in the Lower Amazonian Basin. Trans R Soc Trop Med Hyg 1968 ; 62:385-395

20. Lainson R, Shaw JJ. New World Leishmaniasis. In: Cox FEG, Kreir JP, Wakeli D, editors. Microbiology and Microbial Infections, Parasitology. Sydney: Topley \& Wilson's Auckland; 2005. p.313-349.

21. Ward R, Lainson R, Shaw JJ. Further evidence of the role of Lutzomyia flaviscutellata (Mangabeira) as the vector of Leishmania mexicana amazonensis in Brazil. Trans R Soc Trop Med Hyg 1973; 67:608-609.

22. Ready PD, Lainson R, Shaw JJ. Leishmaniasis in Brazil: XX. Prevalence of "enzootic rodent leishmaniasis" (Leishmania mexicana amazonensis) and apparent absence of "pian-bois" (L. braziliensis guyanensis), in plantations of introduced tree species and in other non-climax forest in eastern Amazonia. Trans R Soc Trop Med Hyg 1983; 77:775-785.

23. Balbino VQ, Coutinho-Abreu IV, Sonoda IV, Marques-da-Silva W, Marcondes CB. Phlebotomine sandflies (Diptera: Psychodidae) of the Atlantic Forest in Recife, Pernambuco state, Brazil: the species coming to human bait, and their seasonal and monthly variations over a 2-year period. Ann Trop Med Parasitol 2005; 99:683-693.

24. Miles MA, Lainson R, Shaw JJ, Povoa A, Souza AA. Leishmaniasis in Brazil: $\mathrm{XV}$. Biochemical distinction of Leishmania mexicana amazonensis, L. braziliensis braziliensis and L. braziliensis guyanensis aetiological agents of cutaneous leishmaniasis in the Amazon Basin of Brazil. Trans R Soc Trop Med Hyg $1981 ; 75: 524-529$

25. Ryan L, Lainson R, Shaw JJ, Neto HF. Ecologia de flebotomíneos (Diptera: Psychodidae: Phlebotominae) na região Amazônica. Instituto Evandro Chagas. Belém. 1986; p.307-315

26. Shaw JJ, Lainson R. Leishmaniasis in Brazil. II. Observations on enzootic leishmaniasis in the lower Amazon region - the feeding habits of the vector Lutzomyia flaviscutellata in reference to man, rodents and other animals. Trans R Soc Trop Med Hyg 1968; 62:396-405.

27. Shaw JJ, Lainson R. Leishmaniasis in Brazil. VI. Observations on the seasonal variations of Lutzomyia flaviscutellata in different types of forest and its relationship to enzootic rodent leishmaniasis (Leishmania mexicana amazonensis). Trans R Soc Trop Med Hyg 1972; 66:709-717.
28. Rebelo JMM, Leonardo FS, Costa JML, Pereira YNO, Silva FS. Flebotomíneos (Diptera: Psychodidae) de área endêmica de leishmaniose na região dos cerrados, Estado do Maranhão, Brasil. Cad Saude Publica 1999; 15:623-630.

29. Ward RD. Studies on the adult and immature stages of some Phlebotomid sandflies (Diptera: Phlebotomidae) in northern Brazil. Londres. [Tese]. [Londres]: Faculdade de Ciências da Universidade de Londres; 1974.

30. Andrade ARO, Nunes VLB, Galati EAB, Arruda CCP, Santos MFC, Rocca MEG et al. Epidemiological study on leishmaniasis in an area of environmental tourism and ecotourism, State of Mato Grosso do Sul, 2006-2007. Rev Soc Bras Med Trop 2009; 42:488-493.

31. Feitosa MAC, Castellón EG. Fauna de flebotomíneos (Diptera: Psychodidae) em fragmentos florestais ao redor de conjuntos habitacionais na cidade de Manaus, Amazonas, Brasil. II. Estratificação horizontal. Acta Amazonica 2004; 34:121-127.

32. Nunes VLB, Galati EAB, Cardozo C, Rocca MEG, Andrade ARO, Santos MFC, et al. Estudo de flebotomíneos (Diptera, Psychodidae) em área urbana do município de Bonito, Mato Grosso do Sul, Brasil. Rev Bras Entomol 2008; 52:446-451.

33. Aguiar GM, Medeiros WM. Distribuição Regional e Habitats das Espécies de Flebotomíneos do Brasil. In: Rangel EF, Lainson R editors. Flebotomíneos do Brasil. Rio de Janeiro: Fundação Oswaldo Cruz; 2003. p. 207-255.

34. Andrade-FilhoJD, Valente MB, Andrade WA, Brazil RP, Falcão AL. Flebotomíneos do Estado do Tocantins, Brasil (Diptera: Psychodidae). Rev Soc Bras Med Trop $2001 ; 34: 323-329$.

35. Dye C, Davies CR, Lainson R. Communication among phlebotomine sandflies: a field study of domesticated Lutzomyia longipalpis populations in Amazonian Brazil. Animal Behaviour 1991; 42:183-192.

36. Morrison AC, Ferro C, Morales A, Tesh R, Wilson ML. Dispersal of the sand fly Lutzomyia longipalpis (Diptera: Psychodidae) at an endemic focus of visceral leishmaniasis in Colombia. J Med Entomol 1993; 30:427-435.

37. Taniguchi HH, Tolezano JE, Corrêa FMA, Moraes RHP, Veiga RMO, Marassá AM. Epidemiologia da leishmaniose tegumentar americana no Estado de São Paulo, Brasil. I-Composição da fauna flebotomínica no município de São Roque, Região de Sorocaba. Rev Inst Adolfo Lutz 1991; 51:23-30.

38. Taniguchi HH, Tolezano JE, Larosa R, Elias CR, Galati EAB. Observações ecológicas de flebotomíneos em área endêmica de leishmaniose tegumentar americana (LTA) no município de Eldorado, Vale do Ribeira, Estado de São Paulo, Brasil, 1996-1997. I-Sazonalidade e freqüência de L. ayrozai em diferentes ecótopos com animais sentinelas em ambiente florestado. Rev Inst Adolfo Lutz 2002; 61:103-112.

39. Kelly DW, Dye C. Pheromones, kairomones and the aggregation dynamics of the sandfly Lutzomyia longipalpis. Animal Behaviour 1997; 53:721-731.

40. Nunes VLB. Condicionantes para a transmissão de leishmanioses em assentamento agrícola do INCRA e adjacências, Planalto da Bodoquena, Estado de Mato Grosso do Sul, Brasil, 1998, 1999. [Tese de Doutorado]. [São Paulo]: Faculdade de Saúde Pública. Universidade de São Paulo; 2001.

41. Nunes VLB, Dorval MEC, Oshiro ET, Noguchi RC, Arão LB, Hans-Filho G, et al. Estudo epidemiológico sobre leishmaniose tegumentar (LT) no município de Corguinho, Mato Grosso do Sul. Estudos na população humana. Rev Soc Bras Med Trop 1995; 28:185-193. 